\title{
Anti-diabetic effect of Stachytarpheta jamaicensis on low dose streptozotocin- induced diabetic rats fed on a high-fat diet
}

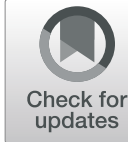

\author{
Mac Donald Idu* D, Owen - Obaseki Edehia and Benjamin Ogunma Gabriel
}

\begin{abstract}
Introduction: This study evaluates the anti-diabetic effect of ethanol extract of Stachytarpheta jamaicensis leaf on streptozotocin (STZ) - induced diabetic rats fed on high-fat diet (HFD).

Methods: Sets of male albino rats of the Wistar strain weighing between 180 and $250 \mathrm{~g}$ were exposed to high fat diet (margarine and oil from vegetable sources in a ratio of 2:1 w/v) for 3 weeks. Then the animals were fasted overnight; hyperglycemic state was induced using reduced dose of streptozotocin (35 mg/kg) and animals were randomly divided into five groups $(n=7)$; group A received the HFD + STZ (35 mg/kg i.p.); group B received HFD + STZ + gliberclamide (10 mg/kg; i.p); groups C, D and E were administered the HFD + streptozotocin with different doses of the ethanol extract (30, 35 and $100 \mathrm{mg} / \mathrm{kg}$ p.o., respectively).

Results: Results showed significant $(p<0.05)$ decrease in blood glucose concentration of the rats treated with different doses of $S$. jamaicensis extract and those treated with gliberclamide compared to the untreated diabetic rats (negative control). Significant $(p<0.05)$ reductions in activities of serum AST, ALP, total protein and bilirubin were noticed in the groups in contrast to the control. Levels of urea, creatinine, potassium and chloride were considerably $(p<0.05)$ low while sodium and bicarbonate levels were high in the groups except the control. Lipid profile revealed significant $(p<0.05)$ reduction in total cholesterol, triacylglycerol, LDL, VLDL while HDL levels were high in the groups compared to the control. The extract significantly $(p<0.05)$ ameliorated weight loss. Histopathology of the liver, kidney and pancreas showed ameliorative effect of the extract against the deleterious changes occasioned by the HFD and STZ induced diabetic state.

Conclusion: These findings have provided scientific basis for the use of S. jamaicensis in the treatment of diabetes mellitus in ethnomedicinal practices in Nigeria.
\end{abstract}

Keywords: Stachytarpheta jamaicensis, Glibenclamide, Streptozotocin, Diabetes mellitus

\section{Introduction}

The prevalence of metabolic syndrome, a group of disorders including obesity, insulin resistance, dyslipidemia and hypertension, has increased globally in recent times. These have subsequently caused an upsurge in the incidence of non-communicable diseases like diabetes mellitus and cardiovascular diseases over the years [1-3].

\footnotetext{
* Correspondence: mcdonald@uniben.edu

Phytomedicine Unit, Department of Plant Biology and Biotechnology, University of Benin, PMB, 1154 Benin City, Edo State, Nigeria
}

Diabetes mellitus (DM), a chronic metabolic disease, occurs when there is improper control of an initial prediabetes state of an individual leading to hyperglycemia and other associated metabolic challenges [4]. DM has been reported to be one of the most common chronic disease with 387 million reported cases in 2014 and an expected 600million more in 2035 [4, 5]. Thus, DM has become a major global health problem in developed countries and now more evidently in developing countries [1-3].

\section{Springer Open}

(- The Author(s). 2021 Open Access This article is licensed under a Creative Commons Attribution 4.0 International License, which permits use, sharing, adaptation, distribution and reproduction in any medium or format, as long as you give appropriate credit to the original author(s) and the source, provide a link to the Creative Commons licence, and indicate if changes were made. The images or other third party material in this article are included in the article's Creative Commons licence, unless indicated otherwise in a credit line to the material. If material is not included in the article's Creative Commons licence and your intended use is not permitted by statutory regulation or exceeds the permitted use, you will need to obtain permission directly from the copyright holder. To view a copy of this licence, visit http://creativecommons.org/licenses/by/4.0/. 
Amongst the different forms of diabetes, type 2 diabetes (T2D) is the most common with $95 \%$ prevalence globally [3]. T2D is caused by impaired insulin action and secretion due to insulin resistance. In order to maintain glucose homeostasis, over secretion of basal insulin by the beta cells occurs which ultimately leads to pancreatic beta cells dysfunction []. Several studies have shown that long -term feeding on high fat diet (HFD) may contribute to the development of metabolic syndrome and eventually metabolic related diseases such as diabetes mellitus [4567]. Besides, HFD has been implicated in causing oxidative stress, obesity, hyperglycemia, hyperlipidemia, hyperphagia, inflammation, insulin resistance and high blood pressure []. Intake of dietary high fat diet triggered the occurrence and development of the onset of hyperglycemia via accumulated body weight resulted from obesity [7]. Prolonged intake of high fat diet induces insulin resistance as a result of excessive weight gain, with change in insulin secretory capacity causing hyperinsulinemia. High fat diet increases mitochondrial $\mathrm{H}_{2} \mathrm{O}_{2}$ discharge latent, a factor responsible for more oxidized redox environment [4].

Although, diet restrictions, exercise and numerous anti-diabetes drugs (e.g. metformin, glibenclamide, vildagliptin, etc) have been employed in the management of T2D, the morbidity and mortality rates of the disease still remains of public health concern. Hence, the need for continuous search for new, effective and more tolerable alternative anti-diabetic agents from natural products of plant origin. Plants have been of great medicinal value to mankind for decades due to their inherent bioactive constituents that can aid primary health care in the treatment, prevention and suppression of various degenerative diseases. Scientific evidence and clinical trials are essential to identify the pharmacologically active secondary metabolites that are present in these plants to validate their folklore uses [8]. Medicinal plants usage as alternatives to orthodox drugs in the treatment of diseases have been well documented for decades $[2,9,10]$. Besides, the secondary metabolites (including phenolic compounds, tannins, saponins, flavonoids, terpenoids, alkaloids, anthocyanidins, cardiac glycosides, steroids) present in these plants have been widely reported to exhibit myriad medicinal properties, such as anti-diarrheal, anti-microbial, anti-oxidant, analgesic, anti-diabetic, anti-hypertensive, anti-inflammatory and antinociceptive properties [11-16].

Stachytarpheta jamaicensis (L.) Vahl, a member of the Verbanaceae family, is locally claimed by ethnomedicinal practitioners to have anti-diabetes activity. Its common names include Gervao, verbena cimarrona, Brazilian tea, blue porter weed and rooter comb [11-17]. It's mostly grown in tropical zones of America, subtropical forest of Oceania, Asia and Africa. The plant is also used medicinally as therapy for respiratory ailments, allergic conditions, constipation, digestive impediment, cough, cold, fever, dysentery, to support mensuration among other therapies [18]. This study sets out to evaluate the anti-diabetic property of Stachytarpheta jamaicensis leaf in streptozocin - induced diabetic rats fed on a high fat diet. The objective showed that, the therapeutic effect of Stachytarpheta jamaicensis aid in the management of high fat diet induce hyperglycemia.

\section{Materials and methods}

\section{Collection of plant material}

The leaf of Stachytarpheta jamaicensis were collected from Ovia North East, Benin City, Edo State, Nigeria and was identified and authenticated by Prof. MacDonald Idu in the Herbarium Unit of the Department of Plant Biology and Biotechnology, Faculty of Life Sciences, University of Benin, Edo State, Nigeria.

\section{Preparation of plant material}

The leaves were rinsed in clean water, shade - dried for 21 days and oven-dried at $40^{\circ} \mathrm{C}$ for $24 \mathrm{~h}$. The dried leaves were powdered using the British milling machine. The weight of the pulverized leaves was taken. Powdered plant sample weight was taken and the extraction processes were carried out; pulverized leaves weighing 1500 g were extracted using ethanol as solvent. The concentrated ethanol extract weighed $156.64 \mathrm{~g}$ and was stored for further uses.

\section{Experimental animals}

Fifty (50) healthy albino rats of both sexes weighing (180-250 g) were obtained from the Department of Biochemistry, University of Benin animal house. The animals were housed in a well-ventilated wooden cages under normal laboratory conditions $(12 \mathrm{~h}$ light/dark cycle: $23 \pm 2{ }^{\circ} \mathrm{C}$ ) and fed with standard constituted diet. Food and water were given ad libitum to all the animals used for the experiments and were handled following standard protocols on the use of laboratory animals (National Institute of Health USA: Public Health Service Policy on Humane Care and use of Laboratory Animals, 2002) throughout the experimental period. Ethical approval (LS20112) was acquired from the ethical committee of Faculty of Life Sciences, University of Benin, Benin City.

\section{Experimental protocol}

\section{Hyperlipidemia and hyperglycemic induced diabetes}

Sets of albino rats were divided into five (5) groups of ten (10) rats each. High fat diet (containing $20 \mathrm{~g}$ of Blue Band $^{\circ}$ margarine ( $0 \%$ energy carbohydrate, $87 \%$ energy calories $100 \%$ energy fat, $0 \%$ energy protein, $0 \%$ fiber) in $100 \mathrm{~mL}$ of Kings $\mathrm{Oil}^{\circ}{ }^{\circ}$ (120\% energy calories; 0\% energy 
carbohydrate; $100 \%$ energy fat; $0 \%$ energy protein) was orally (p.o.) administered to the experimental rats for three (3) weeks. A reduced dose of streptozotocin (35 $\mathrm{mg} / \mathrm{kg}$ body weight; i.p) was also administered to same animals for $48 \mathrm{~h}$ in order to induce diabetes. Five (5) groups of 10 animals per group received: groups $\mathrm{A}=$ Heavy fat diet + streptozotocine (35 $\mathrm{mg} / \mathrm{kg} 1 . \mathrm{p})$, group $\mathrm{B}=$ Heavy fat diet + streptozotocine (35 mg/kg 1.p) + Gliberclamide $(10 \mathrm{mg} / \mathrm{kg}$ o.p), group $\mathrm{C}$ to $\mathrm{E}=$ Heavy fat diet + streptozotocine ( $35 \mathrm{mg} / \mathrm{kg}$ 1.p) + ethanol extract of Stachytarpheta jamaicensis at 30, 50 and $100 \mathrm{mg} / \mathrm{kg}$ p.o). The animals were fasted overnight prior to the administration of Streptozotocine according to their body weight, sugar level was checked at baseline and during treatment for days 7 and 14. The animals were sacrificed and blood sample, liver, kidney and pancreas were isolated for analysis.

\section{Determination of biochemical parameters}

Blood samples collected were spun in a centrifuge and the serum were extracted and used for biochemical analysis. Renal Function Test were carried out using the method described by Schales and Schales [19], Magoshes and Vallee [20]. Liver Function Test were analyzed with the protocol described by Reitman and Frankel [21], Trinder [22]. Lipid profile were carried out with a standard protocol of Tietz [23].

\section{Histological study}

The organs (liver, kidney, and pancreas) were carefully removed and weighed individually and fixed in $10 \%(\mathrm{v} / \mathrm{v})$ formaldehyde, cleaned up in xylene and embedded in a paraffin wax (melting point at 56\%). Tissue sections were prepared according to the method of Drury and Wallinton [24] and stained with eosin / hematoxylin. Photomicrographs were taken at $\times 400$ using a digital camera.

\section{Statistical analysis}

Data were presented as mean \pm SEM of the respective replicates. Means of different groups were compared using ANOVA. Tukey's post hoc test was used to test for significance among the groups. $P$ values $\leq 0.05$ (95\% confidence interval) was considered significant. Graph Pad Prism 6, 2009 version, computer software package was employed.

\section{Results}

Table 1 show the effect of different doses of Stachytarpheta jamaicensis extract on lipid profile of streptozotocin induced diabetic rats fed on a high fat diet. The result showed significant $(p<0.05)$ decrease in blood glucose concentration in the S. jamaicensis extract (at various doses) treated rats and gliberclamide treated rats, on days 7 and 14 of the study, in comparison with the untreated diabetic rats (negative control). However, the decrease was more noticeable on day 14 across the groups, especially the 50 and $100 \mathrm{mg} / \mathrm{kg}$ group when compared to the negative control.

Table 2 represents the effect of $S$. jamaicensis extract on some liver function parameters in streptozotocin induced diabetic rats fed on high fat diet. The results showed significant $(p<0.05)$ reduction in activities of aspartate amino transferase (AST) and alkaline phosphatase (ALP) of the S. jamaicensis extract treated rats and the gliberclamide treated rats when compared with the negative control. The only exception was the rats treated with $100 \mathrm{mg} / \mathrm{kg}$ of the extract which showed nonsignificant $(p>0.05)$ changes in ALP activity. The alanine amino transferase (ALT) and gamma-glutamyl transferase (GGT) activities were non-significantly $(p>$ 0.05 ) different in all the groups from the negative control values. The total protein, total bilirubin, conjugated and unconjugated bilirubin concentrations were significantly $(p<0.05)$ reduced in all the groups except for the $S$. jamaicensis extract treated group at $100 \mathrm{mg} / \mathrm{kg}$ body weight which showed similar values as the negative control.

The results in Table 3 show the effect of S. jamaicensis extract and gliberclamide treatments on kidney function in streptozocin induced diabetic rats fed on high fat diet. There were significant $(p<0.05)$ increase in sodium and bicarbonate levels in all the groups except for the $S$. jamaicensis extract $(100 \mathrm{mg} / \mathrm{kg})$ group which showed non-significant changes $(p>0.05)$ as the negative

Table 1 Effect of Stachytarpheta jamaicensis extract on blood glucose concentration of streptozotocin induced diabetic rats fed on a high fat diet

\begin{tabular}{lllll}
\hline Groups & Dose $\mathbf{~ m g / k g}$ & Base line (mg/dL) & $\begin{array}{l}\text { Day } \mathbf{7} \\
(\mathbf{m g} / \mathbf{d L})\end{array}$ & $\begin{array}{l}\text { Day } \mathbf{1 4} \\
(\mathbf{m g} / \mathbf{d L})\end{array}$ \\
\hline Streptozotocin & 35 & $281.7 \pm 12.73$ & $298.7 \pm 1.45^{\mathrm{a}}$ & $463.0 \pm 85.11^{\mathrm{a}}$ \\
Gliberclamide & 10 & $243.0 \pm 17.21$ & $102.0 \pm 16.77^{\mathrm{c}}$ & $92.67 \pm 8.25^{\mathrm{c}}$ \\
Stachytarpheta jamaicensis & 30 & $315.7 \pm 4.06$ & $186.0 \pm 66.34^{\mathrm{b}}$ & $125.0 \pm 23.39^{\mathrm{b}}$ \\
Stachytarpheta jamaicensis & 50 & $217.0 \pm 8.08$ & $96.00 \pm 5.13^{\mathrm{c}}$ & $71.67 \pm 5.18^{\mathrm{c}}$ \\
Stachytarpheta jamaicensis & 100 & $269.3 \pm 19.20$ & $103.7 \pm 9.74^{c}$ & $76.00 \pm 4.51^{c}$ \\
\hline
\end{tabular}

Values are expressed as mean $\pm \mathrm{SEM}, n=10$ /group. Columns bearing different letters are significantly $(p<0.05)$ different, while those with the same letters are not significantly different 
Table 2 Effect of Stachytarpheta jamaicensis extract on liver function of streptozotocin induced diabetic rats fed on a high fat diet

\begin{tabular}{|c|c|c|c|c|c|c|c|c|c|}
\hline Groups & $\begin{array}{l}\text { Dose } \\
\mathrm{mg} / \mathrm{kg}\end{array}$ & $\begin{array}{l}\text { AST } \\
\text { (U/L) }\end{array}$ & $\begin{array}{l}\text { ALT } \\
\text { (U/L) }\end{array}$ & $\begin{array}{l}\text { ALP } \\
\text { (U/L) }\end{array}$ & $\begin{array}{l}\text { GGT } \\
(\mathrm{U} / \mathrm{L})\end{array}$ & $\begin{array}{l}\text { Total } \\
\text { protein } \\
\text { (g/dL) }\end{array}$ & $\begin{array}{l}\text { Total } \\
\text { bilirubin } \\
\text { (mg/dL) }\end{array}$ & $\begin{array}{l}\text { Conjugated } \\
\text { bilirubin (mg/ } \\
\mathrm{dL})\end{array}$ & $\begin{array}{l}\text { Unconjugated } \\
\text { bilirubin (mg/dL) }\end{array}$ \\
\hline Streptozotocin & 35 & $67.00 \pm 1.16^{a}$ & $21.67 \pm 2.73^{a}$ & $28.33 \pm 0.88^{a}$ & $1.05 \pm 0.09^{a}$ & $38.00 \pm 0.58^{\mathrm{a}}$ & $0.16 \pm 0.01^{a}$ & $0.09 \pm 0.01^{\mathrm{a}}$ & $0.07 \pm 0.01^{\mathrm{a}}$ \\
\hline Gliberclamide & 10 & $32.70 \pm 7.18^{b}$ & $22.60 \pm 2.58^{a}$ & $12.62 \pm 3.37^{b}$ & $0.53 \pm 0.05^{c}$ & $11.22 \pm 1.98^{c}$ & $0.04 \pm 0.00^{c}$ & $0.02 \pm 0.01^{c}$ & $0.02 \pm 0.00^{d}$ \\
\hline S. jamaicensis & 30 & $35.27 \pm 3.59^{b}$ & $13.95 \pm 1.10^{b}$ & $13.63 \pm 2.74^{b}$ & $0.69 \pm 0.05^{b}$ & $14.65 \pm 1.09^{c}$ & $0.05 \pm 0.02^{c}$ & $0.02 \pm 0.01^{c}$ & $0.03 \pm 0.00^{c}$ \\
\hline S. jamaicensis & 50 & $42.04 \pm 6.01^{c}$ & $23.55 \pm 1.24^{a}$ & $18.25 \pm 0.72^{b}$ & $0.29 \pm 0.02^{c}$ & $23.41 \pm 1.55^{c}$ & $0.06 \pm 0.01^{b}$ & $0.02 \pm 0.00^{c}$ & $0.03 \pm 0.01^{c}$ \\
\hline S. jamaicensis & 100 & $36.88 \pm 3.10^{b}$ & $19.08 \pm 1.75^{b}$ & $21.72 \pm 3.40^{\mathrm{a}}$ & $0.88 \pm 0.03^{\mathrm{a}}$ & $34.46 \pm 0.53^{\mathrm{a}}$ & $0.07 \pm 0.02^{b}$ & $0.03 \pm 0.00^{c}$ & $0.03 \pm 0.00^{c}$ \\
\hline
\end{tabular}

Values are expressed as mean \pm SEM, $n=10$ /group. Columns bearing different letters are significantly $(p<0.05)$ different, while those with the same letters are not significantly different. AST Aspartate amino transferase, ALT Alanine amino transferase, ALP Alkaline phosphatase, GGT Gamma-glutamyl transferase

control. The urea, creatinine, potassium and chloride levels were all considerably low $(p<0.05)$ in all the groups in contrast to the negative control values.

The effect of $S$. jamaicensis extract and gliberclamide treatments on lipid profile of streptozocin induced diabetic rats fed on high fat diet is presented in Table 4 . The results revealed significant $(p<0.05)$ reduction in the serum levels of cholesterol, triacylglycerol, LDL cholesterol and VLDL in comparison to the negative control. However, the rats treated with the $S$. jamaicensis extract at $30 \mathrm{mg} / \mathrm{kg}$ and $50 \mathrm{mg} / \mathrm{kg}$ body weight showed nonsignificant changes in their VLDL levels compared to the negative control. HDL cholesterol concentration was significantly high in all the groups when compared to the negative control group.

Figure 1 represents the body mass indices of streptozocin induced diabetic rats fed on high fat diet and treated with $S$. jamaicensis extract. The results showed weight gains in all the groups on days 1, 7 and 14 of exposing the animals on high fat diet prior to streptozotocin (STZ) induction. Thereafter, rapid reduction in the body weight was observed in the groups from day 21 as a result of STZ induction. While significant $(p<0.05)$ increase in the body weight was noticed in all the groups at day 28.

Rapid reduction in the body weight was observed at day 28 of the final body weight across the treated groups when compared with the untreated group. As shown in Fig. 1a.

Effect of Stachytarpheta jamaicensis extract on some organ weight of streptozotocin induced diabetic rats fed on a high fat diet is shown in Table 5. Results showed significant $(p<0.05)$ reduction in the liver and kidney (left and right kidneys) weights of the rats treated with different doses of $S$. jamaicensis extract in comparison with the negative control. However, the gliberclamide treated group had similar liver and kidney weights as the negative control $(p>0.05)$.

Effect of Stachytarpheta jamaicensis extract on lipid profile on streptozotocin induced diabetic rats fed on a high fat diet is shown in Fig. 2. Results showed significant $(p<0.05)$ reduction in the level of cholesterol, triglyceride low density lipoprotein and very low density lipoprotein with an increase in high density lipoprotein of the rats treated with different doses of $S$. jamaicensis extract in comparison with the negative control. However, the gliberclamide treated group had similar results as the treated groups $(p>0.05)$.

Plate 1 shows the histopathology sections of the hepatocytes of streptozotocin induced diabetic rats fed on a high fat diet and treated with different doses of $S$. jamaicensis extract and the anti-diabetic drug, gliberclamide. Section of the hepatocytes of the untreated negative control rats showed centriole with noticeable inflammatory cells surrounding it. The hepatocytes also revealed mild stenosi and some fatty changes. However, the hepatocytes of the diabetic rats treated with $30 \mathrm{mg} / \mathrm{kg}$ of $S$. jamaicensis extract reveals visible centriole, well fenestrated sinusoids, pyknotic nucleus and mild fatty changes. The diabetic rats treated with $50 \mathrm{mg} / \mathrm{kg}$ of $S$. jamaicensis extract showed hepatocyte sections with

Table 3 Effect of Stachytarpheta jamaicensis extract on kidney function of streptozotocin induced diabetic rats fed on a high fat diet

\begin{tabular}{llllllll}
\hline Groups & Dose $\mathbf{m g} / \mathbf{k g}$ & $\begin{array}{l}\text { Creatinine } \\
(\mathbf{m g} / \mathbf{d L})\end{array}$ & Urea $\mathbf{( m g / d L )}$ & $\begin{array}{l}\text { Bicarbonate } \\
(\mathbf{m m o l} / \mathbf{L})\end{array}$ & $\begin{array}{l}\mathbf{N a} \\
(\mathbf{m m o l} / \mathbf{L})\end{array}$ & $\begin{array}{l}\mathbf{K} \\
(\mathbf{m m o l} / \mathbf{L})\end{array}$ & $\begin{array}{l}\mathrm{Cl}^{-} \\
(\mathbf{m m o l} / \mathbf{L})\end{array}$ \\
\hline Streptozotocin & 35 & $0.27 \pm 0.01^{\mathrm{a}}$ & $37.17 \pm 4.52^{\mathrm{a}}$ & $19.92 \pm 1.68^{\mathrm{a}}$ & $99.92 \pm 0.3^{\mathrm{a}}$ & $29.40 \pm 0.65^{\mathrm{a}}$ & $80.25 \pm 2.45^{\mathrm{a}}$ \\
Gliberclamide & 10 & $0.18 \pm 0.02^{\mathrm{c}}$ & $30.83 \pm 3.63^{\mathrm{b}}$ & $24.09 \pm 0.05^{\mathrm{b}}$ & $105.7 \pm 0.7^{\mathrm{b}}$ & $23.08 \pm 0.35^{\mathrm{b}}$ & $61.58 \pm 1.30^{\mathrm{c}}$ \\
S. jamaicensis & 30 & $0.22 \pm 0.01^{\mathrm{b}}$ & $26.09 \pm 0.92^{\mathrm{c}}$ & $21.75 \pm 1.11^{\mathrm{b}}$ & $101.7 \pm 1.6^{\mathrm{b}}$ & $23.28 \pm 0.67^{\mathrm{b}}$ & $71.67 \pm 1.54^{\mathrm{b}}$ \\
S. jamaicensis & 50 & $0.22 \pm 0.01^{\mathrm{b}}$ & $26.42 \pm 1.11^{\mathrm{c}}$ & $21.75 \pm 1.11^{\mathrm{b}}$ & $106.7 \pm 1.4^{\mathrm{b}}$ & $23.81 \pm 0.75^{\mathrm{b}}$ & $63.92 \pm 1.30^{\mathrm{c}}$ \\
S. jamaicensis & 100 & $0.24 \pm 0.01^{\mathrm{a}}$ & $26.92 \pm 0.53^{\mathrm{c}}$ & $18.92 \pm 0.63^{\mathrm{a}}$ & $108.7 \pm 0.1^{\mathrm{b}}$ & $24.62 \pm 0.59^{\mathrm{b}}$ & $66.17 \pm 1.83^{\mathrm{c}}$ \\
\hline
\end{tabular}

Values are expressed as mean \pm SEM, $n=10$ /group. Columns bearing different letters are significantly $(p<0.05)$ different, while those with the same letters are not significantly different 
Table 4 Effect of Stachytarpheta jamaicensis extract on lipid profile of streptozotocin induced diabetic rats fed on a high fat diet

\begin{tabular}{lllllll}
\hline Groups & Dose $(\mathbf{m g} / \mathbf{k g})$ body weight & $\begin{array}{l}\text { Cholesterol } \\
(\mathbf{m g} / \mathbf{d L})\end{array}$ & Triglycerides $(\mathbf{m g} / \mathbf{d L})$ & $\begin{array}{l}\text { HDL } \\
(\mathbf{m g} / \mathbf{d L})\end{array}$ & $\begin{array}{l}\text { LDL } \\
(\mathbf{m g} / \mathbf{d L})\end{array}$ & $\begin{array}{l}\text { VLDL } \\
(\mathbf{m g} / \mathbf{d L})\end{array}$ \\
\hline Streptozotocin & 35 & $93.83 \pm 2.42^{\mathrm{a}}$ & $202.6 \pm 2.94^{\mathrm{a}}$ & $11.18 \pm 0.10^{\mathrm{a}}$ & $42.04 \pm 1.73^{\mathrm{a}}$ & $40.51 \pm 0.59^{\mathrm{a}}$ \\
Gliberclamide & 10 & $61.53 \pm 0.57^{\mathrm{c}}$ & $187.2 \pm 1.61^{\mathrm{c}}$ & $18.07 \pm 0.25^{\mathrm{c}}$ & $6.03 \pm 0.39^{\mathrm{c}}$ & $37.43 \pm 0.32^{\mathrm{b}}$ \\
S. jamaicensis & 30 & $73.07 \pm 0.64^{\mathrm{b}}$ & $194.3 \pm 1.09^{\mathrm{b}}$ & $16.61 \pm 0.31^{\mathrm{b}}$ & $17.60 \pm 0.67^{\mathrm{b}}$ & $38.86 \pm 0.22^{\mathrm{a}}$ \\
S. jamaicensis & 50 & $70.47 \pm 0.29^{\mathrm{b}}$ & $191.0 \pm 0.71^{\mathrm{b}}$ & $16.77 \pm 0.29^{\mathrm{b}}$ & $15.49 \pm 0.08^{\mathrm{b}}$ & $38.21 \pm 0.14^{\mathrm{a}}$ \\
S. jamaicensis & 100 & $61.20 \pm 0.53^{\mathrm{c}}$ & $186.1 \pm 0.81^{\mathrm{c}}$ & $18.47 \pm 0.09^{\mathrm{c}}$ & $5.51 \pm 0.62^{\mathrm{c}}$ & $37.21 \pm 0.16^{\mathrm{b}}$ \\
\hline
\end{tabular}

Values are expressed as mean \pm SEM, $n=10$ /group. Columns bearing different letters are significantly $(p<0.05)$ different, while those with the same letters are not significantly different. HDL High density lipoprotein cholesterol, LDL Low density lipoprotein cholesterol, VLDL Very low density lipoprotein cholesterol

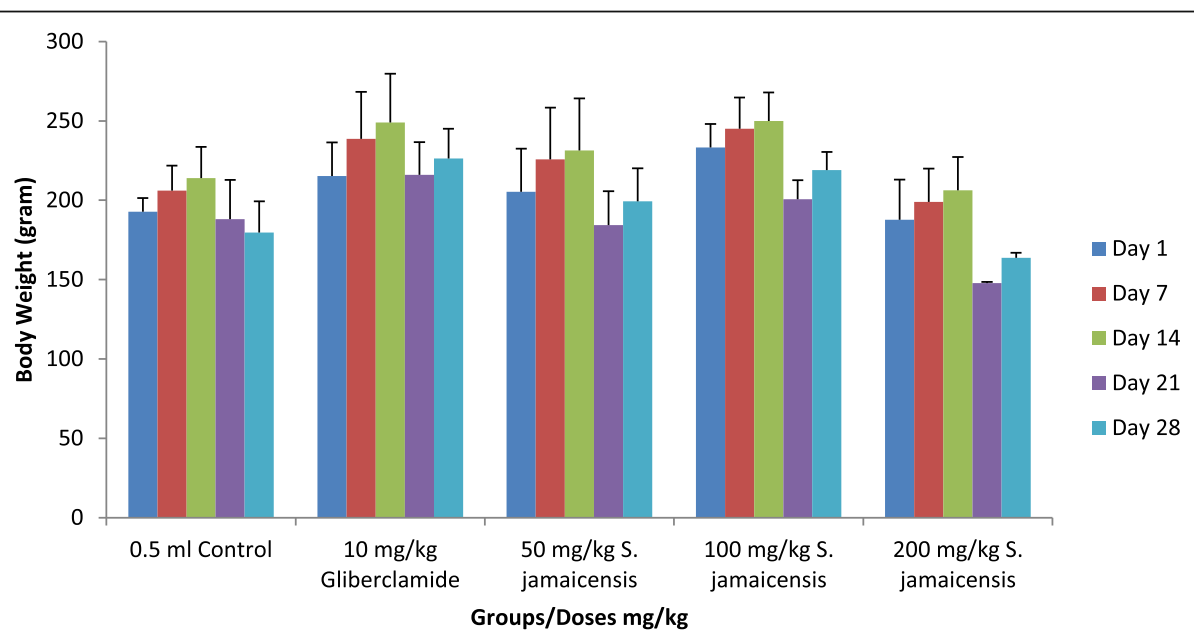

a: Effect of Stachytarpheta jamaicensis on body weight change of Hyperlipidemia and

yperglycemic induced diabetes across the groups.

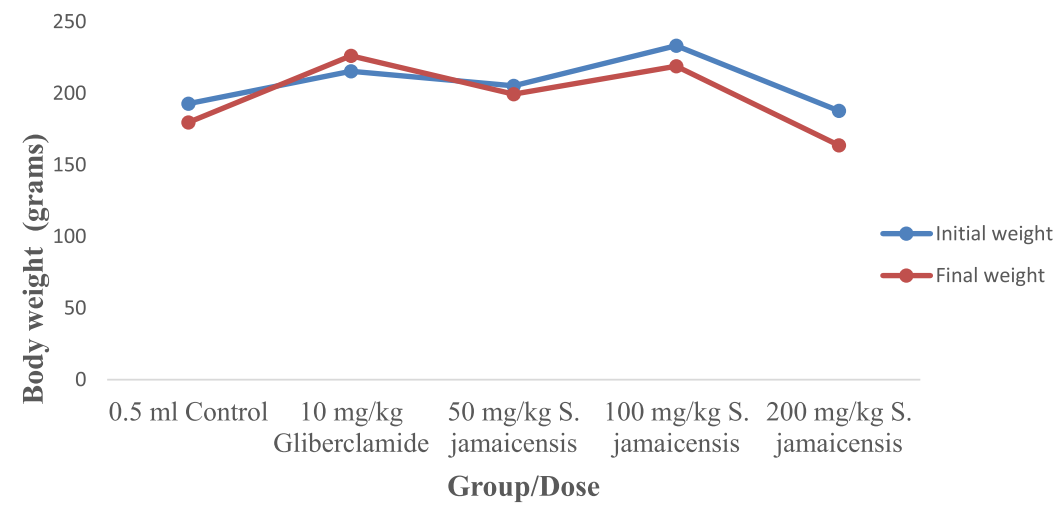

b: Effect of Stachytarpheta jamaicensis on body weight of Hyperlipidemia and Hyperglycemic duced diabetes across the groups.

Fig. 1 a: Effect of Stachytarpheta jamaicensis on body weight change of Hyperlipidemia and Hyperglycemic induced diabetes across the groups. b: Effect of Stachytarpheta jamaicensis on body weight of Hyperlipidemia and Hyperglycemic induced diabetes across the groups 
Table 5 Effect of Stachytarpheta jamaicensis on organ weight of streptozotocin induced diabetic rats fed on a high fat diet

\begin{tabular}{lllll}
\hline Groups & Doses $\mathbf{( m g / k g )}$ & Liver & Left Kidney & Right Kidney \\
\hline Streptozotocin & 35 & $8.99 \pm 0.73^{\mathrm{a}}$ & $0.73 \pm 0.22^{\mathrm{a}}$ & $0.74 \pm 0.23^{\mathrm{a}}$ \\
Gliberclamide & 10 & $8.02 \pm 0.59^{\mathrm{a}}$ & $0.68 \pm 0.18^{\mathrm{a}}$ & $0.70 \pm 0.11^{\mathrm{a}}$ \\
S. jamaicensis & 30 & $7.40 \pm 0.66^{\mathrm{b}}$ & $0.62 \pm 0.16^{\mathrm{b}}$ & $0.61 \pm 0.14^{\mathrm{b}}$ \\
S. jamaicensis & 50 & $7.30 \pm 0.57^{\mathrm{b}}$ & $0.60 \pm 0.11^{\mathrm{b}}$ & $0.62 \pm 0.18^{\mathrm{b}}$ \\
S. jamaicensis & 100 & $7.30 \pm 0.42^{\mathrm{b}}$ & $0.59 \pm 0.14^{\mathrm{b}}$ & $0.58 \pm 0.17^{\mathrm{b}}$
\end{tabular}

Values are expressed as mean \pm SEM, $n=10$ /group. Columns bearing different letters are significantly $(p<0.05)$ different, while those with the same letters are not significantly different

visible centriole, well fenestrated sinusoids and pyknotic nucleus with stenosis. While the $100 \mathrm{mg} / \mathrm{kg}$ treated diabetic rats had similar hepatocyte section as the $50 \mathrm{mg} / \mathrm{kg}$ counterpart except that it shows mild stenosis and some fatty changes. Administration of the anti-diabetic drug, giberclamide, to the diabetic rats revealed hepatocytes showing distinct centriole, well fenestrated sinusoids with mild mononuclear cells.

The histopathology sections of the kidneys of streptozotocin induced diabetic rats fed on a high fat diet and treated with $S$. jamaicensis extract and gliberclamide is shown in Plate 2. Section of the kidney of the untreated diabetic control reveals visible renal corpuscles, interstitial spaces and necrotic tubules. However, treatment of the diabetic rats with $S$. jamaicensis extract at $30 \mathrm{mg} / \mathrm{kg}$ and $50 \mathrm{mg} / \mathrm{kg}$ showed visible renal corpuscles with pyknotic nucleus and visible tubules. Whereas, the $100 \mathrm{mg} / \mathrm{kg}$ treated rats showed visible renal corpuscles with mild inflammatory cells and non-distinct tubules. The gilberclamide treated group showed visible renal corpuscles with interstitial spaces and diffused mononuclear infiltrates.

Plate 3 shows sections of the pancreatic cells of streptozotocin induced diabetic rats fed on a high fat diet and treated with different doses of $S$. jamaicensis extract and the anti-diabetic drug, gliberclamide. The histology sections shows features of some acinar cells with islet-cells showing mildly dispersed pyknotic nuclei and lymphocytic infiltrates as well as visible intralobular duct appearing fatty. While the $S$. jamaicensis extract $(30 \mathrm{mg} / \mathrm{kg})$ treated rats showed pancreatic cells with secretory acini and a pancreatic islet. There were evidence of dispersed pyknotic nuclei with mild lymphocytic infiltrates. The histology section of the pancreas of rats administered $50 \mathrm{mg} /$ $\mathrm{kg}$ and $100 \mathrm{mg} / \mathrm{kg}$ of $S$. jamaicensis extract and those treated with the anti-diabetic drug, gliberclamide revealed some acinar cells with islet-cells showing mildly dispersed pyknotic nuclei and visible lymphocytic infiltrates.

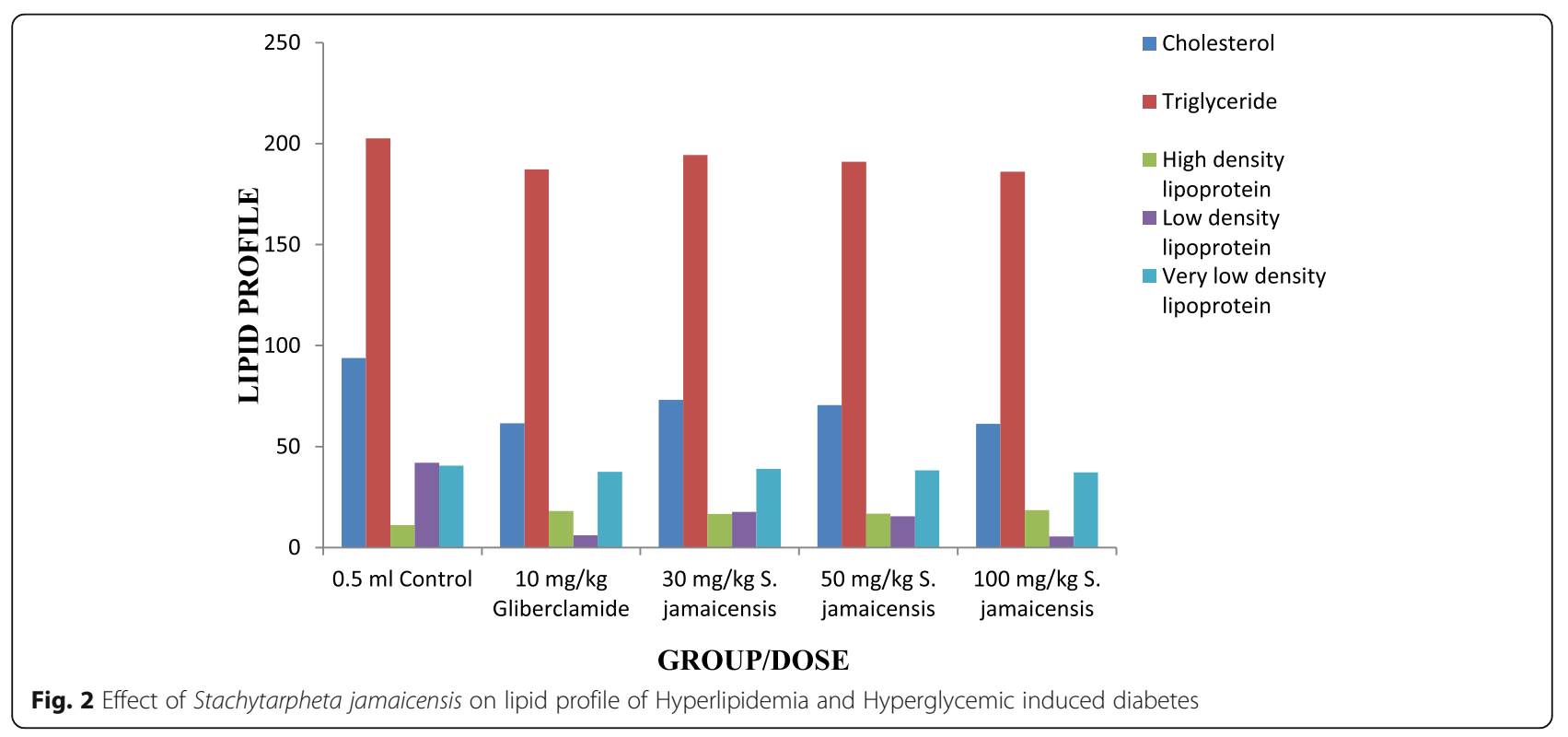



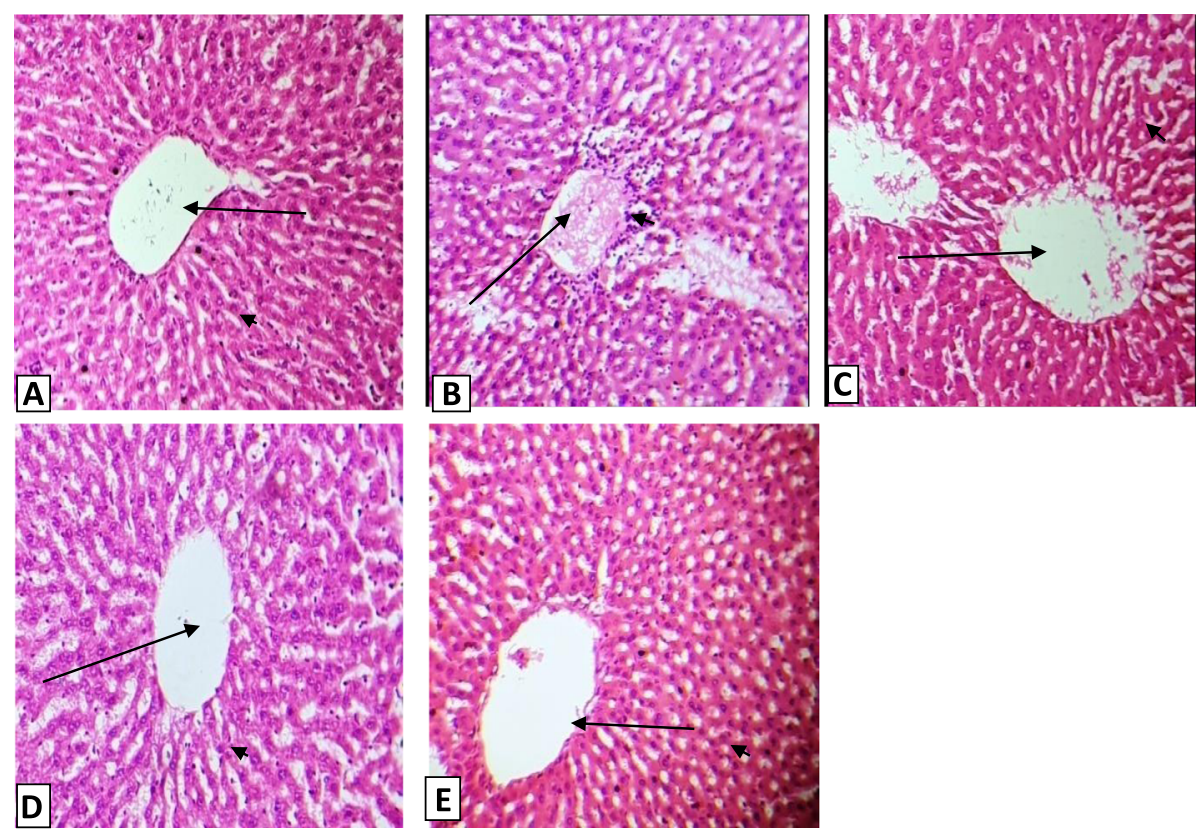

Plate 1 Photomicrograph Sections of the Hepatocytes of Streptozotocin induced Diabetic Rats fed on a High Fat Diet. A= Glibenclamide (10 mg/ $\mathrm{kg}$ ): Section reveals distinct centriole (long arrow) in the hepatocytes and well fenestrated sinusoids with mild mononuclear cells (short arrow). $\mathrm{B}=$ Negative control (untreated): Reveals centriole (long arrow) with noticeable inflammatory cells surrounding it (medium arrow). The hepatocytes shows mild stenosis and fatty changes (short arrow). C = S. jamaicensis extract (30 mg/kg): Features reveal visible centriole (long arrow) with well fenestrated sinusoids. The nucleus appears pyknotic with mild fatty changes (short arrow). $\mathrm{D}=\mathrm{S}$. jamaicensis extract (50 mg/kg): Shows visible centriole (long arrow) with well fenestrated sinusoids and nucleus that appears pyknotic with stenosis (short arrow). $E=S$. jamaicensis extract (100 mg/kg): reveals centriole (long arrow) with pyknotic nucleus and hepatocytes showing mild stenosis and fatty changes (short arrow). [H \& E staining; $\times 40$ magnification]

\section{Discussion}

The combined use of high fat diet (HFD) and low dose of streptozotocin (STZ) to induce type 2 diabetes (T2D) in rat model is well documented in literatures and have been reported to simulate the T2D state and its associated metabolic complications in human $[1-5,25,26]$. For instance, initial report by Kunjathoor et al. [27] showed that albino Wistar rats fed on a high-fat diet and reduced dose of STZ induced hyperglycemia and the animals were found to develop larger fatty stripes, signifying genetic factors in display. The function of PPARs associated with inflammation is particularly pertinent to atherosclerosis and metabolic syndrome, these diseases is as a result of glucose and lipid metabolism with causal inflammatory factors [25]. Nrf2 and NF-kB serves as the major pathways controlling the cellular redox status of fine balance and responses to inflammation and oxidative stress. Interaction between the pathways took place via range of intricate molecular interplay, which often rely on tissue and cell type context [26]. Increases in the occurrence of progressive phases of disease involving; oxidative stress, inflammation, endoplasmic reticulum and mitochondrial dysfunction, which is liable for the development of diseases. Oxidative stress signifies every interference/dysregulation signalling as well as redox stability triggered by increased reactive oxygen species causing oxidative impairment [27]. Endoplasmic Reticulum (ER) stimulates homeostasis via unfolded protein reaction to activate molecular indicators such as; homologous protein, stimulating transcription factor 4 and spliced X-box-binding protein-1 to improve ER stressed state. Thus, persistent ER stress stimuli, triggered inflammatory feedback via initiation of the synthesis of tumour necrotic factor alpha and nuclear transcription factor kappa B thus, instigating apoptosis which suppresses anti-apoptotic factors [26, 27].

Similarly, in the present study, male albino Wistar rats pre-exposed to double challenge of HFD and low-dose $(35 \mathrm{mg} / \mathrm{kg}$ ) of STZ for 14 days demonstrated evidence of hyperlipidemia and hyperglycemia consistent with the T2D state. Blue Band ${ }^{\bullet}$ margarine and King's $s^{\oplus}$ oil (ratio 2: 1) were used in this study to increase the amount of fat in the diet of the animals in order to induce hyperlipidemia in the animals. The HFD given to these animals might have resulted in insulin resistance and glucose intolerance while the low dose of STZ may cause destruction of few pancreatic beta cells leading to T2D associated dyslipidemia [26]. Although, insulin concentration and glucose intolerance were not measured in this study, but there were evidence of elevated levels of 


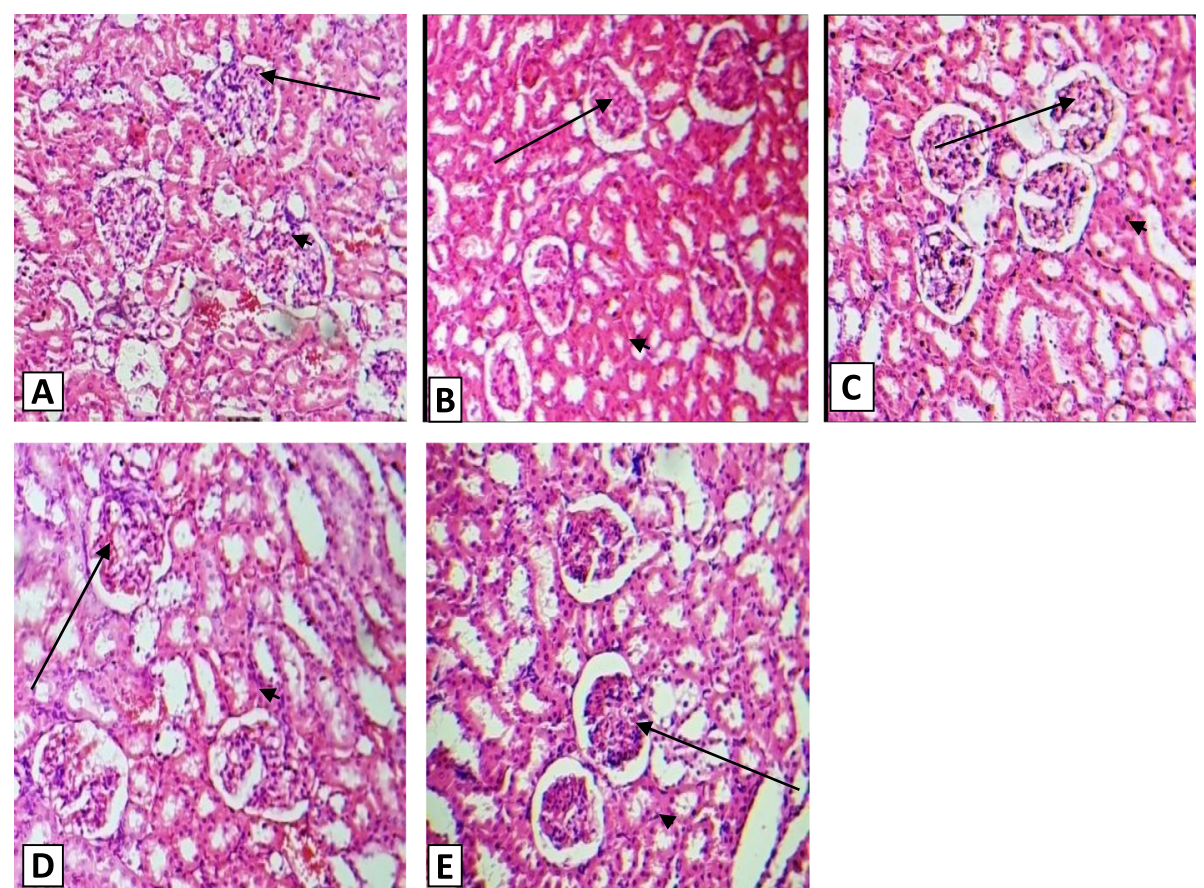

Plate 2 Photomicrograph Sections of the Kidneys of Streptozotocin induced Diabetic Rats fed on a High Fat Diet. A=Glibenclamide (10 mg/kg): Features reveal visible renal corpuscles (long arrow), interstitial spaces (short arrow) and tubules with diffused mononuclear infiltrates. $B=$ Negative control (untreated): Shows visible renal corpuscles (long arrow), interstitial spaces (short arrow) and tubules showing tubular necrosis. $C=S$. jamaicensis extract $(30 \mathrm{mg} / \mathrm{kg}$ ): Reveals visible renal corpuscles (long arrow) with pyknotic nucleus and visible tubules (short arrow). $D=S$. jamaicensis extract $(50 \mathrm{mg} / \mathrm{kg}$ ): Section shows visible renal corpuscles with pyknotic nucleus (long arrow) and visible tubules (short arrow). $E=S$. jamaicensis extract $(100 \mathrm{mg} / \mathrm{kg}$ ): Shows visible renal corpuscles (long arrow) with mild inflammatory cells surrounding it (short arrow) and the tubules appeared not so distinct. [H \& E staining; $\times 40$ magnification]

glucose (hyperglycemia), body weight, fat (hyperlipidemia), some liver and kidney function parameters in the HFD + STZ fed rats which invariably are common in T2D condition.

However, the fasting blood glucose levels of the diabetic rats treated with ethanol extract of Stachytarpheta jamaicensis leaf at various doses (30, 50 and $100 \mathrm{mg} / \mathrm{kg}$ ) were significantly $(p<0.05)$ reduced on days 7 and 14 when compared with the untreated diabetic control. These findings concurred with that of Odetola et al. [28]. It could thus be suggested that the Stachytarpheta jamaicensis leaf extract may possess hypoglycemic property. Similar findings have been reported by Chukwuma et al. [29] which showed the glucose lowering effect of Citrus paradisi in alloxan-induced diabetic rats. Also, Owolabi et al. [30] reported blood glucose lowering effect of ethanol extract of Newboudia laevis leaves across days 4, 8 and 14 of their treatment. Administration of 50 and $100 \mathrm{mg} / \mathrm{kg}$ of ethanol extract of S. jamaicensis showed more significant $(p<0.05)$ reduction in blood glucose levels on days 7 and 14 indicating that the extract may display better effect on blood glucose levels at these higher doses compared to the lowest dose $(30 \mathrm{mg} / \mathrm{kg})$. The hypoglycemic effect of ethanol extract of $S$. jamaicensis leaf on the diabetic rats may be attributed to the phytochemical constituents inherent in the plant. Previous preliminary screening of the plant's phytochemicals showed that it is rich in saponins, flavonoids, tannins, alkaloids and terpenoids [18]. These phytochemicals have been reported to play important roles in ameliorating diabetes related disorders [4-31].

For instance, Miaffo et al. [31] suggested that the antihyperglycemic effect of Vitellaria paradoxa bark in alloxan-induced diabetic rats may be as a result of its phytochemical constituents including glycosides, saponins, phenols, alkaloids and flavonoids. In another study, the insulin-trophic effects of flavonoids have been demonstrated. Flavonoids have been shown to cause a decrease in blood glucose level by altering insulin sensitivity and discharge, glucose transporters, PPAR- $\gamma$, hepatic glucose synthesis and peripheral glucose uptake $[32,33]$. Previous reports suggested that flavonoids actions might be because of residual stimulation of the pancreatic beta cell acting like a sulphonylurea. The work of Odetola et al. [28] also indicated that S. jamaicensis extract elicits anti-hyperglycemic action through extra-pancreatic mechanism attributed to certain saponins and alkaloids present. This however did not support the findings of Owira et al. [33]. 

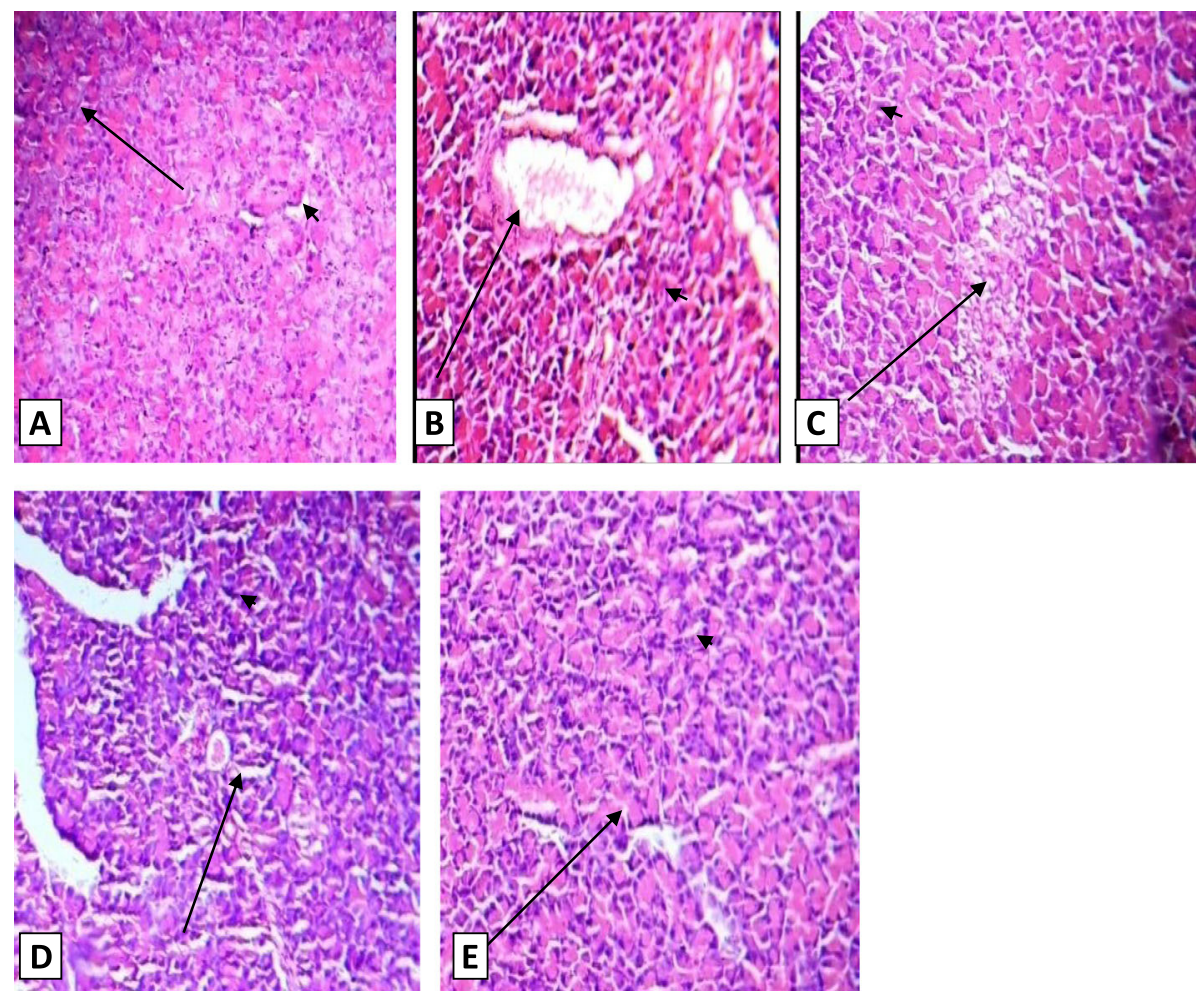

Plate 3 Photomicrograph Sections of the Pancreatic Cells of Streptozotocin induced Diabetic Rats fed on a High Fat Diet. A = Glibenclamide (10 $\mathrm{mg} / \mathrm{kg}$ ): Reveals features of some acinar cells with islet-cells showing mildly dispersed pyknotic nuclei (long arrow) and mild dispersed lymphocytic infiltrates. $B=$ Negative control (untreated): Features show some acinar cells with islet-cells showing mildly dispersed pyknotic nuclei (short arrow) and lymphocytic infiltrates as well as visible intralobular duct appearing fatty (long arrow). C = S. jamaicensis extract (30 mg/kg): Shows secretory acini with a pancreatic islet (long arrow). Histology reveals dispersed pyknotic nuclei with mild lymphocytic infiltrates (short arrow). $\mathrm{D}=\mathrm{S}$. jamaicensis extract $(50 \mathrm{mg} / \mathrm{kg}$ ): Features show some acinar cells with islet-cells showing mildly dispersed pyknotic nuclei (long arrow) and visible lymphocytic infiltrates (short arrow). $\mathrm{E}=\mathrm{S}$. jamaicensis extract $(100 \mathrm{mg} / \mathrm{kg})$ : Features show some acinar cells with islet-cells showing mildly dispersed pyknotic nuclei (long arrow) and visible lymphocytic infiltrates (short arrow). [H \& E staining; $\times 40$ magnification]

Body weight loss is a common feature seen in diabetes mellitus due to the degradation of structural proteins and muscle wasting [34]. Miafflo et al. [31] suggested that during weight loss as a result of diabetes, there is breakdown of protein and lipid stores in muscle tissues as alternative sources of energy due to insulin resistance leading to inability to utilize blood glucose. In this study, the diabetic rats treated with extract of $S$. jamaicensis leaf, at graded doses, significantly $(p<0.05)$ reduced weight loss at 28 days. The extract was probably able to control muscle atrophy by inhibiting the rate of weight loss associated with diabetes mellitus. This result is consistent with previous report of Murunga et al. [35] who revealed that naringin, a component of grapefruit ameliorates weight loss in streptozotocin-induced diabetic rats.

A myriad of biochemical parameters are altered in HDF with low-dose STZ induced diabetes mellitus such as, renal function, liver function and lipid profiles. Many plants with anti-diabetic activity are effective in the maintenance of renal function, liver function and lipid profiles. Hyperglycemia is reported to be responsible for any increments seen in diabetes $[35,36]$. The high levels of urea as seen in this study may be attributed to the use of gluconeogenesis as an alternative source of glucose due to insulin deficiency [37]. Gluconeogenesis rate is increased as a result of elevated proteolysis which produces glycogenic amino acids; subsequently undergo deamination in the liver leading to high urea levels [37].

The significant $(p<0.05)$ reduction in serum levels of urea and creatinine in the $S$. jamaicensis extract and glibenclamide treated groups as observed in this study suggest nephron-protective effects of the extract which is consistent with Chukwuma et al. [29] work. Similar effects have been reported by Osigwe et al. [36] in alloxan induced diabetic rats given extracts of Newboudia laevis for 21 days. Kidney being a major visceral organ is involved in waste products elimination with renal function tests seeking to confirm the presence or absence of dysfunction. Also, phytochemicals, such as flavonoids, tannins, and some pure compounds (phenolic acids, chlorogenic acid, catechin, sterols) reported to be 
present in the plant leaf might have contributed to the nephron-protective effect of the extract by acting as antioxidants to enhance insulin sensitivity thereby decrease gluconeogenesis and proteolysis [18-36] Bioactive chemicals / compounds from extracts of S. jamaicensis leaf have been reported to possess antioxidative as well as anti-inflammatory properties.

Low bicarbonate level is a feature which characterize diabetic ketoacidosis which is seen in mainly type 1 but also type 2 diabetes mellitus under conditions of metabolic stress [38]. Therefore, the significant $(p<0.05)$ increase in bicarbonate levels in the groups treated with $S$. jamaicensis extract and the glibenclamide indicates a reversal of the diabetic induced ketoacidosis. Hyponatremia is a common feature seen in diabetes mellitus owing to osmotic diuresis [39]. From the data obtained on serum sodium levels, compared to the untreated diabetic control, the extract and the glibenclamide treated groups showed significant $(p<0.05)$ increase in sodium levels which indicate their ability to prevent hyponatremia due to decreased osmotic diuresis. In the case of potassium levels, the significant $(p<0.05)$ decrease in potassium levels in the S. jamaicensis extract and the glibenclamide treated diabetic groups suggesting the ability of the extract/glibenclamide to reverse hyperkalaemia associated with T2D. Hyperkalemia is seen in a significant number of diabetic patients and is mostly due to hyporeninemic hypoaldosteronism caused by diabetic nephropathy [39].

Hyperchloremia is a common feature in poorly controlled diabetes associated with hyperglycaemia, ketosis and acidosis. It is an indicator of progressive renal decline. From the chloride ion levels obtained in this study, there were significant $(p<0.05)$ reduction in chloride levels in the $S$. jamaicensis extract and the glibenclamide treated diabetic groups compared with the untreated diabetic control. It can be further inferred here that the extract / glibenclamide showed renoprotective effects on the diabetic rats due to their hypochloremia properties. The effects of the extracts on the renal parameters are similar to previous studies of Chukwuma et al. [29] and Osigwe et al. [40] who both showed the renoprotective effects of Citrus paradisci juice and Newbouldia laevis leaf extract respectively in alloxan induced diabetic rats.

The significant $(p<0.05)$ increase in serum hepatic enzymes (especially AST, ALP, GGT) activities as seen in the untreated diabetic control group in this study could be attributed to hyper-toxic effect of the combined administration of the high fat diet with the streptozotocin [40]. Increased ALP activity might suggest cell membrane peroxidation leading to loss of the integrity of the cell membrane. ALT has been shown to take part in transamination of amino acids and insulin suppresses its transcription. Impairment in insulin activity is suggested to cause increased activity of ALT [40, 41]. Compared to the untreated diabetic control, the $S$. jamaicensis extract treated diabetic groups showed significant $(p<0.05)$ reductions in ALP levels. The same can be said of the effect of glibenclamide. However, relative to the untreated diabetic control, the $S$. jamaicensis extract and the glibenclamide treated diabetic groups exhibited nonsignificant changes in ALT activities; while the AST activities were significantly $(p<0.05)$ reduced. Decrease in activities of the hepatic enzymes as observed in the diabetic rats treated with $S$. jamaicensis extract could be due to its possible hepatoprotective and antioxidant effects of the extracts [40-42]. The direct bilirubin did not significantly $(p>0.05)$ change across the groups investigated.

Goldberg [43] reported that deficits in insulin production or sensitivity are associated with lipid abnormalities contributing to conditions such as atherosclerosis and fatty liver disease This was evident from the statistically significant $(p<0.05)$ elevation in the total cholesterol, triglyceride, LDL-C and decrease in HDL-C levels in the untreated diabetic rats (negative control). Whereas, administration of different doses of the $S$. jamaicensis extract to the diabetic rats resulted in the observed hypolipidemic effect of the extract in contrast to the negative control. The hypolipidaemic effects seen in these groups supports previous works of Castilla et al. [41] and Odetola et al. [28] who respectively showed the hypolipidaemic effect of Citrus paradisi juice and aqueous extract of fermented Parkia biglobosa in alloxaninduced diabetic rats. It is also similar to a study carried out by Owolabi et al. [42] on the hypolipidaemic effects of Napoleona vogelis methanol leaf extract. The increase in the levels of HDL-C termed 'good cholesterol' and the decrease in LDL-C termed 'bad cholesterol' as a result of administration of $S$. jamaicensis extract enhances its role as dietary supplements which could prevent cardiovascular complications of diabetes such as dyslipidaemia because a high HDL-C/LDL-C ratio shows a lower risk of coronary heart disease [42].

Histopathology of the excised organs was informative. The liver of the normal control revealed no evidence of fatty hydropic changes or inflammation explaining why all liver biochemical parameters were low. This is in stark contrast to the livers of the rats in which diabetes had been induced with a high fat diet plus streptozotocin. The liver of the diabetic control rat showed prominent fatty changes and the presence of inflammatory cells, with the portal vein appearing congested (Plate 1). This could be attributed to the fact that cholesterol and streptozotocin causes hepatocellular generation, oxidative stress, inflammation and hepatic steatosis in the liver of rats [40]. High fat diet triggered oxidative stress, obesity and pro-inflammatory defect. Hence, it stimulates a prolipogenic conditions in liver and hepatic steatosis. 
Therefore, hepatic steatosis is directly associated with increased activation of transcription factor SREBP-1c and a decrease in the effect of transcription factor PPARalpha $[25,26]$. These are some cardinal features which characterize the progression of hyperlipidaemia and diabetes mellitus. This is supported by the elevation of liver enzymes and lipid profiles of the untreated diabetic rats. Non-alcoholic fatty liver disease is a condition which characterizes poorly controlled diabetes mellitus [44, 45].

Treatment with graded doses of ethanol extract of Stachytarpheta jamaicensis leaf reduces the degree of degeneration of the hepatocytes. This may be due to the presence of antioxidant and anti-inflammatory principles in this plant. For example, Citrus paradisi which contains antioxidants such as naringin, narigenin, resveratrol, vitamins $C$ and $E$ have been reported to protect the liver [46]. Histopathology of the kidneys of normal rats reveals an intact architecture devoid of atrophy, necrosis or inflammation. This is in contrast with the kidneys of the diabetic untreated rats which showed atrophy of the renal corpuscles and the presence of visible inflammatory infiltrates. This shows that heavy fat diet plus streptozotocin enhances nephrotoxic and hepatic toxicity, thus explaining the alteration in liver biochemical parameters seen []. The kidneys of the rats treated with 30 , 50 and $100 \mathrm{mg} / \mathrm{kg}$ ethanol extracts of $S$. jamaicensis respectively had better architecture than the untreated diabetic rats as they were devoid of atrophy, necrosis or inflammation (Plate 2). Thus, suggesting that the extracts are nephroprotective. This is supported by the renal biochemical parameters of the extract treated rats, which were statistically different from that of the untreated rats $(p<0.05)$.

These observations might be attributed to antioxidant and anti-inflammatory principles present in the extracts. Besides, Fuji et al. [48] showed that proanthrocyanidins had the strongest protective effect against high glucose mediated oxidative stress on cultured kidney cells. The pancreas of the normal control revealed architecture devoid of lymphocytic infiltration, congestion or atrophy. This was in contrast with the pancreas of the untreated diabetic rats, which revealed lymphocytic infiltrations and pyknotic cell congestion. This observation is in tandem with the cytotoxic effects of high fat diet plus streptozotocin on the pancreas of rats which might have led to $\beta$ cell damage and consequently hyperglycaemia [47]. Section of the pancreas of the rats treated with various doses of Stachytarpheta jamaicensis extracts revealed marked improvements over the diabetic untreated (Plate 3) [44].

\section{Conclusion}

The findings from this study have shown the antihyperglycaemic, antidyslipidemic, hepatoprotective and nephron-protective effects of ethanol extract of $S$. jamaicensis at various doses in diabetic rats as a result to their exposure to a high fat diet and low dose streptozotocin. The higher doses (50 and $100 \mathrm{mg} / \mathrm{kg}$ ) of the extract reduced blood glucose concentration more significantly in the diabetic rats than the lower dose $(30 \mathrm{mg} / \mathrm{kg})$. Furthermore, $S$. jamaicensis extract significantly ameliorated changes in biochemical indices usually associated with the diabetic state. These findings have provided scientific basis for the use of $S$. jamaicensis in the treatment of diabetes mellitus in ethnomedicinal practices in Nigeria.

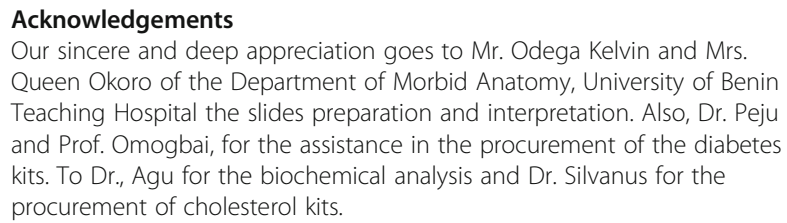

\section{Authors' contributions}

Owen - Obaseki Edehia carried out the research work (antidiuretic and antidiabetic) under the co-supervision of Gabriel Ogunma Benjamin and supervision of MacDonald Idu. All authors read and approved the final manuscript.

\section{Funding}

Not applicable for this section.

\section{Availability of data and materials}

Data where obtained from this research study and statistically analysed as shown in the result Tables, Figures and Plates. Materials such as chemicals, drugs, kits and animals where ordered from necessary stores within and out the country.

\section{Declarations}

Ethical approval and consent to participate

All procedures using animals obtained the approval of Life Sciences Institutional Animal Ethical Committee, University of Benin with LS20112 ethical number.

Consent for publication

Not applicable for this section.

\section{Competing interests}

Absent competing interest.

Received: 22 July 2020 Accepted: 7 November 2021

Published online: 07 December 2021

\section{References}

1. Kaur G, Meena C. Amelioration of obesity, glucose intolerance and oxidative stress in high-fat diet and low dose streptozotocin-induced diabetic rats by combination consisting of curcumin with piperine and quercetin. ISRN Pharmacol. 2012, pp 1-7. https://doi.org/10.5402/2012/957283.

2. Cha J, Redivo DDB, Gasparin AT, Sotomaior BB. Cannabidiol attenuates mechanical allodynia in streptozotocin-induced diabetic rats via serotonergic system activation through 5-HT1A receptor. Brain Res. 2019; 372:111992.

3. Chen Y, Yang D, Cheng B. Clinical characteristics and outcomes of patients with diabetes and COVID-19 in association with glucose-lowering medication. Diabetes Care. 2020;43:1399-407.

4. Chang W, Chen L, Hatch GM. Berberine as a therapy for type 2 diabetes and its complications: from mechanism of action to clinical studies. Biochem Cell Bio. 2014;1(5):1-8. https://doi.org/10.1139/bcb-2014-0107. 
5. Khadke SP, Harke SM, Ghade AA, Kuvalekar A. Association of fasting plasma glucose and serum lipids in type 2 diabetics. Indian J Pharm Sci. 2015;77(5): 630-4.

6. Ezuruike $U$, Prieto JM. The use of plants in the traditional management of diabetes in Nigeria :pharmacological and toxicological considerations. J Ethnopharmacol. 2014;155(2):857-924. https://doi.org/10.1016/j.jep.2014.05 055 .

7. Campbell K, Rossi F, Adams J, Pitsidianaki I, Barriga FM, Carcia-Gerique L, et al. Collective cell migration and metastases induced by an epithelial-tomesenchymal transition in drosophilia intestinal tumor. Nat Commun. 2019. 10(1):2311. https://doi.org/10.1038/s41467-019-10269-y.

8. Abdel-lateif KS, Maghrabi IA, Eldeab HA. Plants source with therapeutic benefits against diseases. J Bioprocess Biotech. 2016;6(293):1-7.

9. Zhang RH, Mustafa AF, Zhao X. Effect of feeding oilseeds on nutrient utilization by lactating ewes. Small Rumin Res. 2007;67(2-3):307-11. https:// doi.org/10.1016/j.smallrumres.2005.11.004.

10. Zheng $M$, Li M, Fei Z, Wu F, Li Y, Pan Y, et al. A deep learning framework for identifying essential proteins by intergrating multiple types of biological information. IEEE/ACM Trans Comput Biol Bioinform. 2019.

11. Lahlou M. Novel agent findings and development. Pharmacol Pharm. 2013; 4(03):17-31. https://doi.org/10.4236/pp.2013.43A003.

12. Babu KS, Naik VKM, Latha J, Ramanjaneyulu K. Bioactive phytochemicals. Intern J Pharm Pharm Res Hum. 2016;7(1):380-93.

13. Dhawale PG, Ghyare BP. Advantages of the plant's natural products. J Nat Sc Res. 2016;6(3):30-5.

14. Carmona F, AMSB P. Secondary metabolites. J Pharmacog. 2013;23(2):37985. https://doi.org/10.1590/S0102-695X2013005000018.

15. Misra L. Organic and natural products. Intern J Trad Nat Med. 2013;2(1):2775.

16. Sasidharan S, Chen Y, Saravanan D, Sundram KM, Latha LY. Pharmacologically active secondary metabolites effective in plants. Afri J Trad Complemen Altern Med. 2011;8(1):1-10. https://doi.org/10.4314/ajtcam. v8i1.60483.

17. Debbiea S, Graeme L, Pierrec D, Elizabethd W, Kelvine CJ. Sympathetic pharmacokinetics, safety, efficacy, drug interactions and bioavailability of therapeutic agent. Ethnopharmacol. 2012;140:513-8.

18. Idu M, Omogbai EKI, Aghimien GE, Amaechina F, Timothy O, Omonigho SE. Preliminary phytochemistry, antimicrobial properties and acute toxicity of Stachytarpheta jamaicensis (L.) Vahl leaves. Trends Med Res. 2007;2(4):193-8.

19. Schales O, Schales SS. A simple and accurate method for the determination of chloride in biological fluids. J Biol Chem. 1941;140(5):879-82. https://doi. org/10.1016/S0021-9258(18)72872-X

20. Magoshes V. Flame photometry and spectrophotometry and spectrometry. J Intern Sc. 1956:2(1):13-6.

21. Reitman S, Frankel S. Liver function analysis. Am J Clin Path. 1957;28(1):5663. https://doi.org/10.1093/ajcp/28.1.56.

22. Trinder $P$. Determination of glucose in blood using glucose oxidase with an alternative oxygen receptor. Ann Clin Biochem. 1969;6(1):24-7. https://doi. org/10.1177/000456326900600108.

23. Tietz NW. Clinical Guide to Laboratory Test. 3rd ed. Philadelphia: WB Sanders Company; 1995. p. 518-9.

24. Drury RAB, Wallinton EA. Carletons: Histological Technique. 16th ed. London: Oxford University Press; 2013. p. 124-36.

25. Reed MJ, Meszaros K, Entes LJ, Claypool MD, Pinkett JG, Gadbois TM, et al. A new rat model of type 2 diabetes: the fat-fed, streptozotocin-treated rat. Metab-Clin Exp. 2000;49(11):1390-4. https://doi.org/10.1053/meta.2000.1 7721.PMID:11092499.

26. Srinivasan K, Viswanad B, Asrat L. Combination of high-fat diet-fed and lowdose streptozotocin-treated rat: a model for type 2 diabetes and pharmacological screening. Pharmacol Res. 2005;52(4):313-20. https://doi. org/10.1016/j.phrs.2005.05.004.

27. Kunjathoor W, Wilson DL, LeBeouf RC. Increased atherosclerosis in streptozotocin induced diabetic mice. J Clin Invest. 1996;97(7):1767-73. https://doi.org/10.1172/JCl118604

28. Odetola AA, Akinloye O, Egunjobi C, Adekunle WA, Ayoola AO. Possible antidiabetic and antihyperlipidaemic effect of fermented Parkia biglobosa (Jacq) extract in alloxan induced diabetic rats. Clin Exp Pharmacol Physiol. 2006;33(9):808-12. https://doi.org/10.1111/j.1440-1681.2006.04444.x.

29. Chukwuma OO, Chidozie EA, Ikenna IK, Augusta NC, Jeremiah OS. Antidiabetic and renal protective effect of the fruit juice of Citrus $X$ Paradisi on alloxan induced diabetic male albino Wistar rats. Der Pharmacia Lett. 2016; 8(19):32-8. http://scholarsresearchlibrary.com/archive.html.

30. Owolabi OJ, Amaechina FC, Okoro M. Effect of ethanol leaf extract of Newboulda Laevis on blood glucose levels of diabetic rats. Trop J Pharm Res. 2011;10(3):249-54 Available online at http://www.tjpr.org/10.4314/tjpr. V10i3.12.

31. Miaffo D, Kamgue OG, Kamanyi A. Antidiabetic and antioxidant potentials of Vitellaria paradoxa barks in alloxan-induced diabetic rats. Clin Phytosc. 2019; 5(1):44. https://doi.org/10.1186/s40816-019-0141-z.

32. Kameswaararao B, Kesavulu MM, Apparao C. Hepatic glucose synthesis and peripheral glucose uptake. Fitoterapia. 2003;74:7-13.

33. Owira PMO, Ojewole JAO. Grapefruit juice improves glycaemic control but exacerbates metformin-induced lactic acidosis in diabetic rats. Methods Exp Clin Pharmacol. 2009;31(9):563-70.

34. Alarcon C, Wicksteed B, Prentki M, Corkey BE, Rhodes CJ. Succinate is a preferential metabolic stimulus-coupling signal for glucose-induced proinsulin biosynthesis translation. Diabetes. 2002;51(8):2496-504. https:// doi.org/10.2337/diabetes.51.8.2496.

35. Murunga AN, Miruka DO, Driver C, Nkomo FS, Cobongela SZZ, Owira PMO Grape fruit Derived Flavonoid Naringin Improves Ketoacidosis and Lipid Peroxidation in Type 1 Diabetes Rat Model. PLoS One. 2016;11(4):e0153241. https://doi.org/10.1371/journal.pone.0153241.

36. Osigwe CC, Akah PA, Nworu CS. Biochemical and haematological effects of the leaf extract of Newbouldia laevis in alloxan- induced diabetic rats. J Biosci Med. 2017;5(06):18-36. https://doi.org/10.4236/jbm.2017.56003.

37. Wild S, Roglic G, Green A, Sicree R, King H. Global prevalence of diabetes estimates for the year 2000 and projections for 2030. Diabetes Care. 2004; 27(5):1047-53. PMID: 15111519. https://doi.org/10.2337/diacare.27.5.1047.

38. Eleazu CO, Iroaganachi M, Eleazu KC. Ameliorative potentials of cocoyam (Colocasia esculenta L.) and unripe plantain (Musa paradisiaca L.) on the relative tissue weights of streptozotocin-induced diabetic rats. J Diabetes Res. 2013;(160964):8. https://doi.org/10.1155/2013/1609640

39. Miikue-Yobe TFB, Uwakwe AA, Akaninwuor JO. Effect of aqueous leaf extract of Heinisia crinata on hematological and some biochemical indices of toxicity in streptozocin induced diabetic rats. Intern J Innovat Sci Res. 2015; 2:116-26.

40. Buchner I, Medeiros N, Lacerda D, Normann BM, Gemelli T, Rigon P, et al. Hepatoprotective and antioxidant potential of organic and conventional grape juices in rats fed a high-fat diet. Antioxidant. 2014;3(2):323-38. https:// doi.org/10.3390/antiox3020323.

41. Castilla B, Patricia E. Concentrated red grape juice extract antioxidant, hypolipidemic, and anti-inflammatory effects in both hemodialysis patients and healthy subjects. Am J Clin Nutr. 2006;84(1):252-62.

42. Owolabi OJ, Inninh SO, Anaka NO, Iyamu OA. Antidiabetic and hypolipidemic effects of methanol leaf extract of Napoleona vogelii (Lecythidaceae) Hook \& Planch on Alloxan-induced diabetes mellitus in rats. Trop J Pharm Res. 2014 13(11):1903-9. https://doi.org/10.4314/tjpr.v13i11.19.

43. Goldberg I. Diabetic dyslipidemia: causes and consequences. J Clin Endocrinol Metab. 2001;86(3):965-71. https://doi.org/10.1210/jcem.86.3.7304.

44. Ataman JE, Idu M, Odia EA. Histopathologic effects of Stachytarpheta jamaicensis (L.) Vahl onWistar rats. Pakistan J Biol Sci. 2006;9(3):477-82. https://doi.org/10.3923/pjbs.2006.477.482.

45. Oyedemi SO, Adewusi EA, Aiyegoro OA, Akinpeanolu DA. Antidiabetic and hematological effect of aqueous extract of stem bark of Afzelia africana (Smith) on streptozocin-induced diabetic wister rats. Asian Pacif J Trop Biomed. 2011;1:353-8.

46. Alam M, Subhan N, Rahman M, Uddin J, Reza M, Sarker D. Effect of citrus flavonoids, naringin and naringenin, on metabolic syndrome and their mechanisms of action. Adv Nutr. 2014;5(4):404-17. https://doi.org/10.3945/a n.113.005603.

47. Ogunyinka BI, Oyinloye BE, Osunsanmi FO, Opoku AR, Kappo AP. Modulatory influence of Parkia biglobosa protein isolate on testosterone and biomarkers of oxidative stressin brain and testes of streptozotocin-induced diabetic male rats. Intern J Physiol Pathophysiol Pharmacol. 2016;8(3):78-86.

48. Fuji H, Yokozawa T, Kim YA, Tohga C, Nonaka G. Antioxidant and antiinflammatory principles. Mini Rev Med Chem. 2006;7:663-78.

\section{Publisher's Note}

Springer Nature remains neutral with regard to jurisdictional claims in published maps and institutional affiliations. 